\title{
Mechanism of Stereospecific Production of L-Amino Acids from the Corresponding 5-Substituted Hydantoins by Bacillus brevis
}

\author{
Akihiro Yamashiro, Koji Kubota and Kenzo YokozeKI \\ Central Research Laboratories of Ajinomoto Co., Inc., \\ 1-1, Suzuki-cho, Kawasaki-ku, Kawasaki 210, Japan
}

Received June 7, 1988

\begin{abstract}
The mechanism of stereospecific production of L-amino acids from the corresponding 5substituted hydantoins by Bacillus brevis AJ-12299 was studied. The enzymes involved in the reaction were partially purified by DEAE-Toyopearl $650 \mathrm{M}$ column chromatography and their properties were investigated. The conversion of DL-5-substituted hydantoins to the corresponding $\mathrm{L}$-amino acids consisted of the following two successive reactions. The first step was the ring-opening hydrolysis to $\mathrm{N}$-carbamoyl amino acids catalyzed by an ATP dependent L-5-substituted hydantoin hydrolase. This reaction was stereospecific and the $N$-carbamoyl amino acid produced was exclusively the L-form. $\mathrm{N}$-Carbamoyl-L-amino acid was also produced from the D-form of 5substituted hydantoin, which suggests that spontaneous racemization occurred in the reaction mixture. In the second step, $N$-carbamoyl-L-amino acid was hydrolyzed to L-amino acid by an $N$ carbamoyl-L-amino acid hydrolase, which was also an L-specific enzyme. The ATP dependency of the L-5-substituted hydantoin hydrolase was supposed to be the limiting factor in the production of L-amino acids from the corresponding 5-substituted hydantoins by this bacterium.
\end{abstract}

In our previous paper ${ }^{1)}$ we reported the isolation of a bacterium that directly and stereospecifically produces various L-amino acids, including both aliphatic and aromatic, from the corresponding DL-5-substituted hydantoins, and the effective production of $\mathrm{L}$ valine by a mutant whose $\mathrm{L}$-valine degradation pathway was genetically blocked. We also examined the reaction conditions for the production of L-valine and the culture conditions for the formation of the enzyme involved in the reaction, but the productivity was lower than that of $\mathrm{L}$-tryptophan by a similar reaction using Flavobacterium sp. AJ-3940. ${ }^{2 \sim 4)}$ To find the reason for this low productivity, it was necessary to investigate the properties of the enzymes involved in the reaction.

In this paper, we describe the mechanism of stereospecific production of various $\mathrm{L}$-amino acids from the corresponding DL-5-substituted hydantoins by Bacillus brevis AJ-12299.

\section{MATERIALS AND METHODS}

Microorganisms. The mutant No. 102 derived from $B$. brevis $\mathrm{AJ}-12299$, whose $\mathrm{L}-\mathrm{valine}$ degradation pathway was genetically blocked, was used. ${ }^{11}$

Media. Medium III described previously ${ }^{1)}$ was used for the enzyme formation.

Chemicals. 5-Substituted hydrantoins were prepared from the corresponding amino acids ${ }^{5}$ or aldehydes. ${ }^{6)} \mathrm{N}$ Carbamoyl amino acids were prepared from the corresponding amino acids. ${ }^{7}$ Other chemicals used in this work were the best available commercial products.

Preparation of crude extracts. The cells of $B$. brevis No. 102 cultured at $30^{\circ} \mathrm{C}$ for $16 \mathrm{hr}$ as previously described ${ }^{11}$ were harvested by centrifugation and suspended in $0.1 \mathrm{M}$ Tris- $\mathrm{HCl}$ buffer $(\mathrm{pH} 7.5)$ containing $0.2 \mathrm{mM} \mathrm{MnCl}_{2}$, and then disrupted with a sonic oscillator. The cell debris was removed by centrifugation and the supernatant was used as crude enzyme.

Enzyme assay. The activity of the enzyme involved in the hydrolysis of 5-substituted hydantoins was measured by the rate of the liberation of $N$-carbamoylvaline from L- 
5-isopropylhydantoin. The standard reaction mixture contained $80 \mu \mathrm{mol}$ of $\mathrm{L}$-5-isopropylhydantoin, $40 \mu \mathrm{mol}$ of ATP, $400 \mu \mathrm{mol}$ of $\mathrm{KCl}, 4 \mu \mathrm{mol}$ of $\mathrm{MgSO}_{4}$, and the enzyme in $2.0 \mathrm{ml}$ of $0.1 \mathrm{M}$ Tris- $\mathrm{HCl}$ buffer $(\mathrm{pH} \mathrm{7.5)}$. The reaction was done at $30^{\circ} \mathrm{C}$ for $2 \mathrm{hr}$ and the $N$ carbamoylvaline formed was measured by the method previously reported. ${ }^{8)}$ The activity of $N$-carbamoyl amino acid hydrolyzing-enzyme was measured by the amount of L-valine produced from $N$-carbamoyl-L-valine. The standard reaction mixture contained $40 \mu \mathrm{mol}$ of $N$-carbamoyl$\mathrm{L}$-valine, $20 \mu \mathrm{mol}$ of $\mathrm{FeSO}_{4}$, and the enzyme in $2.0 \mathrm{ml}$ of $0.1 \mathrm{M}$ Tris- $\mathrm{HCl}$ buffer $\left(\mathrm{pH} \mathrm{7.5)}\right.$. After incubation at $30^{\circ} \mathrm{C}$ for $2 \mathrm{hr}$, the L-valine formed was measured by microbioassay using Leuconostoc mesenteroides ATCC-8042.

One unit of each enzyme activity was defined as the amount of the enzyme producting $1 \mu \mathrm{mol}$ of $N$-carbamyl$\mathrm{L}$-valine or L-valine per min under the assay conditions.

Separation of the 5-substituted hydantoin and $\mathrm{N}$ carbamoyl amino acid hydrolyzing-enzymes. The crude extract of $B$. brevis No. 102 described above was dialysed against $20 \mathrm{~mm}$ Tris- $\mathrm{HCl}$ buffer ( $\mathrm{pH} \mathrm{7.5)} \mathrm{containing} 0.2 \mathrm{~mm}$ $\mathrm{MnCl}_{2}$. The dialysate was put on a $2.6 \times 30 \mathrm{~cm}$ column of DEAE-Toyopeal $650 \mathrm{M}$ (Toyo Soda Mfg. Co.) previously equilibrated with the same buffer. After washing with the same buffer, the enzymes were eluted with a linear gradient of $\mathrm{NaCl}(0 \sim 0.5 \mathrm{~m})$ in $20 \mathrm{~mm}$ Tris- $\mathrm{HCl}$ buffer $(\mathrm{pH} 7.5)^{\circ}$ containing $0.2 \mathrm{mM} \mathrm{MnCl}_{2}$, and $10 \mathrm{ml}$ of fractions were collected. The fractions containing the 5-substituted hydantoin or $N$-carbamoyl amino acid hydrolyzing-enzyme were then each mixed and used for the investigation of the properties of the enzymes.

Identification of the configuration of $N$-carbamoyl amino acids produced enzymatically. The configuration of $\mathrm{N}$ carbamoyl amino acids produced enzymatically was identified by analyzing the configuration of amino acids prepared from $\mathrm{N}$-carbamoyl amino acids by the following method. One-tenth $\mathrm{ml}$ of conc. $\mathrm{HCl}$ and the amount of $\mathrm{NaNO}_{2}$ equivalent to $\mathrm{N}$-carbamoyl amino acid measured by the method reported previously ${ }^{8)}$ were added to $1 \mathrm{ml}$ of ice-cooled sample solution. The mixture was kept at $0^{\circ} \mathrm{C}$ for $20 \mathrm{hr}$ and then neutralized with $\mathrm{NaOH}$. The configurations of the amino acids formed were identified by ligand exchange high performance liquid chromatography (HPLC) using a Chiralpak WH column (Daicel Chemical Industries). ${ }^{\prime \prime}$

Analyses. 5-Isopropylhydantoin was measured by HPLC using a Hitachi gel \#3020 column (Hitachi) as previously described. " ATP and ADP were also measured by HPLC using an Inertsil ODS column (Gasukuro Kogyo Inc., $4.6 \times 250 \mathrm{~mm}$ ). Two percent methanol containing $50 \mathrm{~mm}$ potassium phosphate $(\mathrm{pH} 5.0)$ was used as mobile phase at a flow rate of $0.5 \mathrm{ml} / \mathrm{min}$. Inorganic phosphate was measured by Phosphor C-Test (Wako Pure Chemical Industries).

Protein was measured by the method of Bradford ${ }^{9 /}$ using bovine serum albumin as standard.

\section{RESULTS}

The enzymes involved in the conversion of 5substituted hydantoins to L-amino acids

At first, the enzymes involved in the hydrolysis of 5-substituted hydantoins to Lamino acids were investigated using the crude extract as enzyme source, and L-5-isopropylhydantoin and $N$-carbamoyl-L-valine as substrates.

As shown in Table I, L-valine was produced from $N$-carbamoyl-L-valine, a proposed intermediate of the hydrolysis of 5-isopropylhydantoin to L-valine. But the amounts of L-valine and $N$-carbamoylvaline produced were both negligible when L-5-isopropylhydantoin was used as substrate. This finding suggests that the enzyme hydrolyzing 5-substituted hydantoins to $N$-carbamoyl amino acids might require some cofactors. So the activation ef-

\section{Table I. Enzyme Activities in the Crude Extract}

The crude extract of $B$. brevis No. 102 was incubated with (a) $20 \mathrm{~mm} N$-carbamoyl-L-valine, (b) $40 \mathrm{~mm} \mathrm{L-5-}$ isopropylhydantoin, (c) $40 \mathrm{~mm} \mathrm{L-5-isopropylhydantoin,} 20 \mathrm{~mm} \mathrm{ATP,} 200 \mathrm{~mm} \mathrm{KCl}$ and $2 \mathrm{~mm} \mathrm{MgSO}_{4}$, in $0.1 \mathrm{M}$ Tris- $\mathrm{HCl}$ buffer $(\mathrm{pH} 7.5)$. Each reaction was done at $30^{\circ} \mathrm{C}$ for $2 \mathrm{hr}$.

\begin{tabular}{|c|c|c|c|c|}
\hline & \multirow{2}{*}{ Substrates } & \multirow{2}{*}{ Cofactors } & \multicolumn{2}{|c|}{ Products (mM) } \\
\hline & & & $N$-Carbamoylvaline & L-Valine \\
\hline (a) & $N$-Carbamoyl-L-valine & None & - & 4.5 \\
\hline (b) & L-5-Isopropylhydantoin & None & 0.1 & 0.2 \\
\hline (c) & L-5-Isopropylhydantoin & $\mathrm{ATP}, \mathrm{K}^{+}, \mathrm{Mg}^{2+}$ & 3.0 & 0.2 \\
\hline
\end{tabular}


fects of cofactors, such as metal ions, coenzymes, and energy rich compounds were examined. Of all the additives tested, the enzyme was greatly activated by ATP in the presence of $\mathrm{K}^{+}$and $\mathrm{Mg}^{2+}$ ions. As shown in Table $\mathrm{I}$, the formation of a notable amount of $\mathrm{N}$ carbamoylvaline was observed from L-5isopropylhydantoin.

\section{Separation of the 5-substituted hydantoin and} $N$-carbamoyl amino acid hydrolyzingenzymes

As shown in Fig. 1, the 5-substituted hydantoin and $N$-carbamoyl amino acid hydrolyzing-enzymes were eluted at about $0.3 \mathrm{M}$ and $0.15 \mathrm{M} \mathrm{NaCl}$, respectively, on DEAE-
Toyopearl 650M column chromatography, and were completely separated from each other. About 14- and 4.6-fold purification with yields of 75 and $77 \%$ was achieved for the 5-substituted hydantoin and $N$-carbamoyl amino acid hydrolyzing-enzymes, respectively.

Properties of the 5-substituted hydantoin hydrolyzing-enzyme

The effects of cations on the 5-substituted hydantoin hydrolyzing-enzyme were examined in the presence of $20 \mathrm{~mm}$ ATP. The reaction was greatly accelerated in the presence of a high concentration of $\mathrm{K}^{+}(200 \mathrm{~mm})$ or $\mathrm{NH}_{4}{ }^{+}(50 \mathrm{mM})$ ion and a low concentration of $\mathrm{Mg}^{2+}(2 \mathrm{mM})$ or $\mathrm{Mn}^{2+}(2 \mathrm{mM})$ ion.

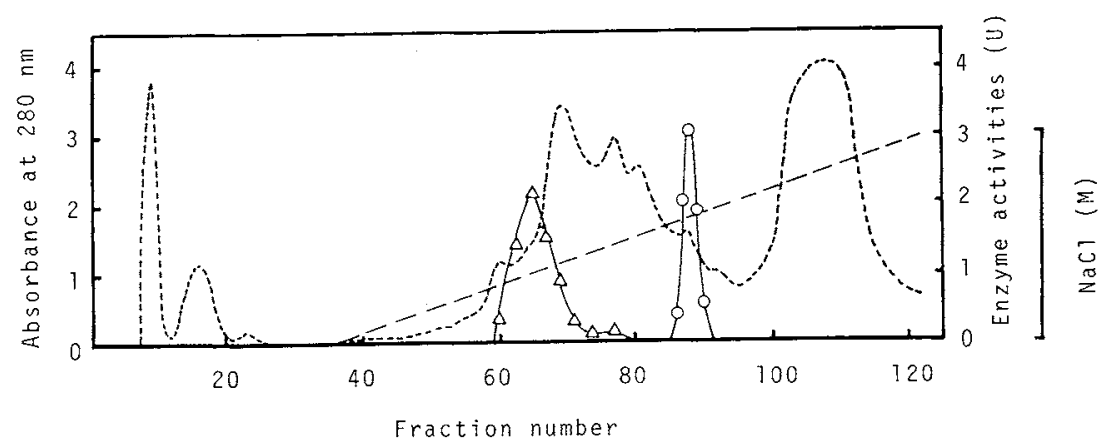

FIG. 1. Separation of the 5-Substituted Hydantoin and $N$-Carbamoyl Amino Acid Hydrolyzing-Enzymes on a DEAE-Toyopearl 650M Column.

The sample contained $898 \mathrm{mg}$ of protein $(51 \mathrm{ml})$; the elution buffer was a continuous $\mathrm{NaCl}$ gradient $(0 \sim 0.5 \mathrm{M})$ in $20 \mathrm{~mm}$ Tris- $\mathrm{HCl}$ buffer ( $\mathrm{pH} \mathrm{7.5)} \mathrm{containing} 0.2 \mathrm{mM} \mathrm{MnCl}_{2}$; the fraction volume was $10 \mathrm{ml} . \bigcirc$, 5-substituted hydantoin hydrolyzing-activity; $\triangle, N$-carbamoyl amino acid hydrolyzing-activity; ------, protein; --- , concentration of $\mathrm{NaCl}$.

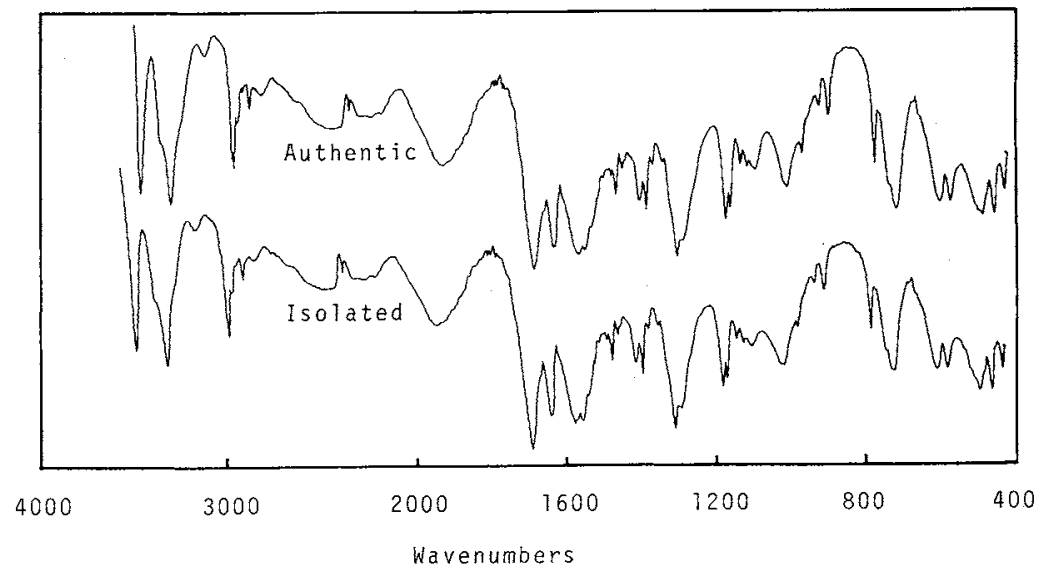

FIG. 2. IR Spectra of Authentic and Isolated $N$-Carbamoylvaline ( $\mathrm{KBr}$ ). 


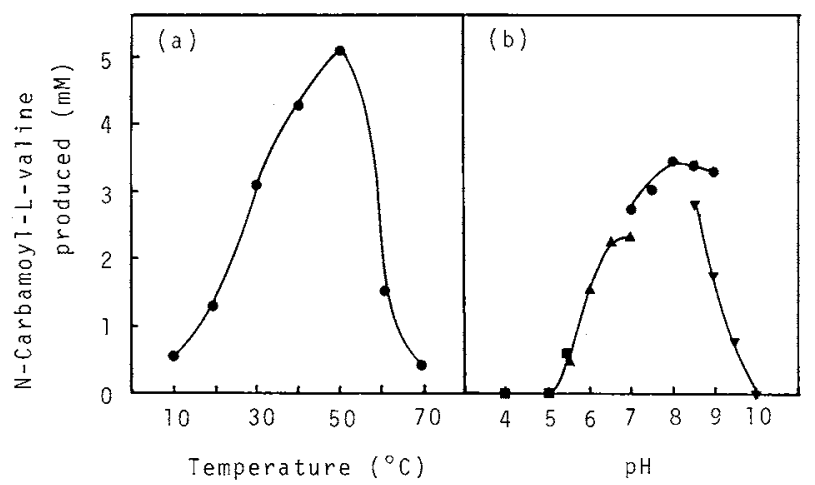

FIG. 3. Effects of Temperature and $\mathrm{pH}$ on the ATP dependent L-5-Substituted Hydantoin Hydrolase.

(a) The activity was measured at $10 \sim 70^{\circ} \mathrm{C}$.

(b) The activity was measured at $\mathrm{pH} 4.0 \sim 10.5$. The buffers used were $0.1 \mathrm{M}$ sodium acetate maleate $(\boldsymbol{\Lambda}), 0.1 \mathrm{M}$ Tris- $\mathrm{HCl}(\boldsymbol{O})$, and $0.1 \mathrm{M}$ sodium carbonate $(\boldsymbol{\nabla})$.

The reaction product from DL-5-isopropylhydantoin was isolated and identified. The reaction mixture contained $40 \mathrm{~mm}$ DL-5-isopropylhydantoin, $40 \mathrm{~mm} \mathrm{ATP,} 200 \mathrm{~mm} \mathrm{KCl,} 2 \mathrm{~mm}$ $\mathrm{MgSO}_{4}$, and the 5-substituted hydantoin hydrolyzing-enzyme in a total volume of $50 \mathrm{ml}$ of $0.1 \mathrm{M}$ Tris- $\mathrm{HCl}$ buffer $(\mathrm{pH} 7.5)$. The reaction was done at $30^{\circ} \mathrm{C}$ for $20 \mathrm{hr}$, and the product was separated by paper chromatography with the solvent system of water- $n$ propanol $=1: 1(\mathrm{v} / \mathrm{v})$. The band of the product on the paper chromatogram was cut off and extracted with hot water. After concentration in vacuo, the product was recrystallized. The crystal showed the same infra-red spectrum pattern as authentic $N$-carbamoyl-Lvaline (Fig. 2).

The configuration of $N$-carbamoylvaline produced from DL-5-isopropylhydantoin was identified. The configuration of valine prepared from $N$-carbamoylvaline by sodium nitrite was found to be exclusively the L-form. This result shows that the stereospecificity of the ATP dependent 5-substituted hydantoin hydrolase of this bacterium was L-specific.

The optimal temperature and $\mathrm{pH}$ were around $50^{\circ} \mathrm{C}$ and 8.0 (Fig. 3). $\mathrm{Km}$ values obtained from Lineweaver-Burk plots were 1.0 and $1.3 \mathrm{~mm}$ for L-5-isopropylhydantoin and ATP, respectively.

The stoichiometry of the reaction was exam-
TABle II. Stoichiometry of the Conversion OF L-5-ISOPROPYLHYDANTOIN TO $N$-CaRBamoYlvaline

The enzyme was incubated with $40 \mathrm{~mm}$ L-5isopropylhydantoin and/or $20 \mathrm{~mm}$ ATP in the presence of $200 \mathrm{mM} \mathrm{KCl}$ and $2 \mathrm{mM} \mathrm{MgSO}_{4}$ in $0.1 \mathrm{M}$ Tris- $\mathrm{HCl}$ buffer (pH 7.5). The reactions were done at $30^{\circ} \mathrm{C}$ for $2 \mathrm{hr}$.

\begin{tabular}{cccccccc}
\hline & \multicolumn{2}{c}{$\begin{array}{c}\text { Consumed } \\
\text { Substrates }\end{array}$} & & \multicolumn{3}{c}{ Formed (mM) } \\
\cline { 2 - 3 } \cline { 5 - 7 } & IPH & ATP & & NCV & ADP & Pi \\
\hline IPH+ATP & 5.6 & 5.4 & & 5.1 & 6.2 & 5.0 \\
IPH & 0 & - & & 0 & - & - \\
ATP & - & 0 & & - & 0 & 0 \\
\hline
\end{tabular}

$\mathrm{IPH}=\mathrm{L}-5$-Isopropylhydantoin; $\mathrm{NCV}=\mathrm{N}$-CarbamoylL-valine.

ined by measuring the 5-isopropylhydantoin and ATP consumed, and the $N$-carbamoyl-Lvaline, ADP and inorganic phosphate produced. As shown in Table II, while $5.6 \mathrm{~mm}$ of L-5-isopropylhydantoin was converted to $5.1 \mathrm{~mm}$ of $N$-carbamoyl-L-valine, $5.4 \mathrm{~mm}$ of ATP was hydrolyzed to $6.2 \mathrm{~mm}$ of ADP and $5.0 \mathrm{~mm}$ of inorganic phosphate. The hydrolyses of L-5-isopropylhydantoin and ATP were not observed in the absence of ATP and L-5isopropylhydantoin, respectively. These results indicate that the hydrolysis of L-5-substituted hydantoins to $N$-carbamoyl-L-amino acids proceeds stoichiometrically in the presence of 
ATP.

Table III shows the substrate specificity of the 5-substituted hydantoin hydrolase. The enzyme had a wide substrate specificity and hydrolyzed various 5-substituted hydantoins to the corresponding $N$-carbamoyl-L-amino acids. The best substrate was 5-methylthioethylhydantoin corresponding to methionine. N-Carbamoyl-L-valine was produced not only from L- and DL-5-isopropylhydantoin but also from D-5-isopropylhydantoin, suggesting that spontaneous racemization occurred in the reaction mixture, just like D-5- benzylhydantoin ${ }^{10)}$ and L-5-(p-hydroxyphenyl)hydantoin. ${ }^{11)}$

Properties of the $N$-carbamoyl amino acid hydrolyzing-enzyme

The effects of cations on the $N$-carbamoyl amino acid-hydrolyzing enzyme were examined. $\mathrm{Mn}^{2+}(2 \mathrm{~mm})$ or $\mathrm{Fe}^{2+}(10 \mathrm{~mm})$ ion was found to activate the enzyme.

The $K m$ value for $N$-carbamoyl-L-valine was $2.0 \mathrm{~mm}$. The optimal temperature and $\mathrm{pH}$ were around $50^{\circ} \mathrm{C}$ and 7.5 (Fig. 4).

Table IV shows the substrate specificity of

Table III. Substrate Specificity of ATP Dependent 5-Substituted Hydantoin Hydrolase

The reaction mixture contained $40 \mathrm{~mm} 5$-substituted hydantoin, $20 \mathrm{~mm} \mathrm{ATP,} 200 \mathrm{~mm} \mathrm{KCl,} 2 \mathrm{~mm} \mathrm{MgSO}_{4}$, and the enzyme in $0.1 \mathrm{M}$ Tris- $\mathrm{HCl}$ buffer $\left(\mathrm{pH} \mathrm{7.5)}\right.$. The reactions were done at $30^{\circ} \mathrm{C}$ for $2 \mathrm{hr}$.

\begin{tabular}{llr}
\hline Substrates & Products & $\begin{array}{c}\text { Relative } \\
\text { value }\end{array}$ \\
\hline L-5-Isopropylhydantoin & $N$-Carbamoyl-L-valine & 100 \\
DL-5-Isopropylhydantoin & $N$-Carbamoyl-L-valine & 100 \\
D-5-Isopropylhydantoin & $N$-Carbamoyl-L-valine & 75 \\
L-5-Isobutylhydantoin & $N$-Carbamoyl-L-leucine & 95 \\
L-5-sec-Butylhydantoin & $N$-Carbamoyl-L-isoleucine & 111 \\
L-5-Methylthioethylhydantoin & $N$-Carbamoyl-L-methionine & 130 \\
L-5-Methylhydantoin & $N$-Carbamoyl-L-alanine & 57 \\
L-5-Benzylhydantoin & $N$-Carbamoyl-L-phenylalanine & 86 \\
L-5- $p$-Hydroxybenzyl $)$ hydantoin & $N$-Carbamoyl-L-tyrosine & 34 \\
DL-5-Cyanoethylhydantoin & $N$-Carbamoyl-L-cyanoethylglycine & ND \\
DL-5-(3,4-Methylenedioxybenzyl)hydantoin & $N$-Carbamoyl-L-3,4-methylenedioxyphenylalanine & ND \\
\hline
\end{tabular}

$\mathrm{ND}=$ detected but not determined.

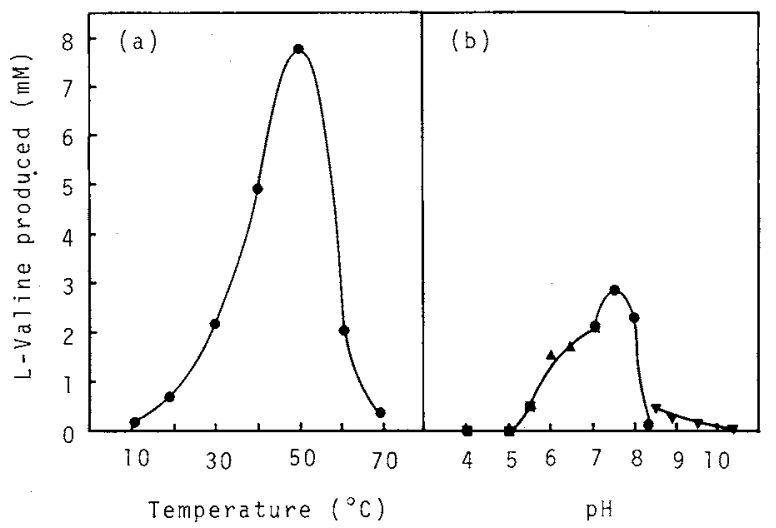

Fig. 4. Effects of Temperature and $\mathrm{pH}$ on the $\mathrm{N}$-Carbamoyl-L-Amino Acid Hydrolase.

(a) The activity was measured at $10 \sim 70^{\circ} \mathrm{C}$.

(b) The activity was measured at $\mathrm{pH} 4.0 \sim 10.5$. The buffers used were $0.1 \mathrm{M}$ sodium acetate ( $\mathbf{\square}$ ), $0.1 \mathrm{M}$ sodium maleate $(\boldsymbol{\Delta}), 0.1 \mathrm{M}$ Tris $-\mathrm{HCl}(\boldsymbol{O})$, and $0.1 \mathrm{M}$ sodium carbonate $(\boldsymbol{\nabla})$. 
Table IV. Substrate Specificity of $N$-Carbamoyl-l-Amino Acid Hydrolase

The reaction mixture contained $40 \mathrm{~mm} N$-carbamoyl amino acid, $20 \mathrm{mM} \mathrm{FeSO}$, and the enzyme in $0.1 \mathrm{M}$ Tris- $\mathrm{HCl}$ buffer ( $\mathrm{pH} 7.5$ ). The reactions were done at $30^{\circ} \mathrm{C}$ for $2 \mathrm{hr}$.

\begin{tabular}{llr} 
Substrates & Products & $\begin{array}{c}\text { Relative } \\
\text { value }\end{array}$ \\
\hline$N$-Carbamoyl-L-valine & L-Valine & 100 \\
$N$-Carbamoyl-DL-valine & L-Valine & 95 \\
$N$-Carbamoyl-L-leucine & L-Leucine & 102 \\
$N$-Carbamoyl-L-isoleucine & L-Isoleucine & 84 \\
$N$-Carbamoyl-L-methionine & L-Methionine & 73 \\
$N$-Carbamoyl-L-alanine & L-Alanine & 48 \\
$N$-Carbamoyl-L-phenylalanine & L-Phenylalanine & 86 \\
$N$-Carbamoyl-L-tyrosine & L-Tyrosine & 45 \\
$N$-Carbamoyl-DL-3,4-methylenedioxyphenylalanine & L-3,4-Methylenedioxyphenylalanine & ND \\
$N$-Carbamoyl-DL-3,4-dimethoxyphenylalanine & L-3,4-Dimethoxyphenylalanine & ND
\end{tabular}

$\mathrm{ND}=$ detected but not determined.

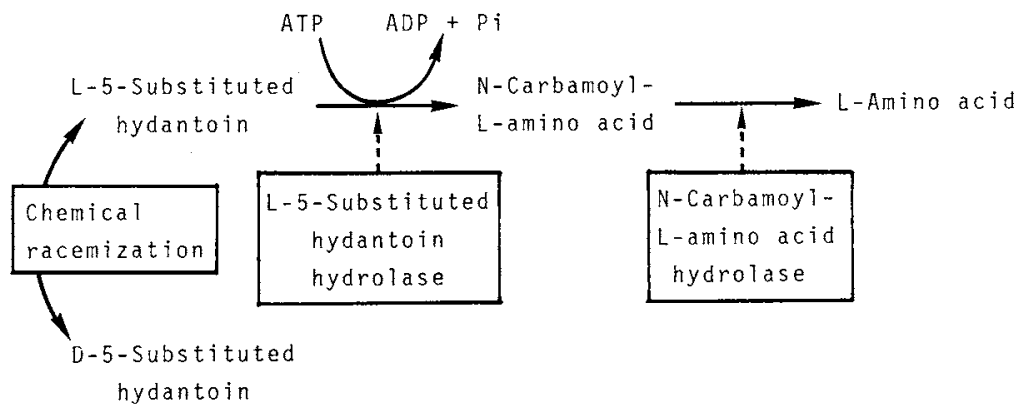

FIG. 5. Proposed Scheme of the Conversion of DL-5-Substituted Hydantoins to L-Amino Acids by B. brevis.

the $N$-carbamoyl amino acid hydrolase. Various $N$-carbamoyl-L-amino acids were hydrolyzed to the corresponding L-amino acids, including both aliphatic and aromatic amino acids. L-Valine production was observed from the L- and DL-forms of $N$-carbamoylvaline, but not from the $\mathrm{D}$-form, and valine produced from $N$-carbamoyl-DL-valine was exclusively the L-form. These results show that the stereospecificity of the $N$-carbamoyl amino acid hydrolase of this bacterium was L-specific.

\section{DISCUSSION}

Bacillus brevis AJ-12299 and its mutant No. 102 produced various $L$-amino acids, including both aliphatic and aromatic L-amino acids, from the corresponding DL-5-substituted hydantoins. In this paper, we described the prop- erties of the enzymes involved in the conversion, that is, the ATP dependent L-5substituted hydantoin hydrolase and the $\mathrm{N}$ carbamoyl-L-amino acid hydrolase. The proposed scheme for the mechanism of the stereospecific production of L-amino acids from DL-5-substituted hydantoins is shown in Fig. 5.

The 5-substituted hydantoin hydrolase of this bacterium is unique because it requires ATP for hydrolysis of the substrates. Recently, Kim et al. ${ }^{12)}$ reported an ATP-dependent $N$ methylhydantoin amidohydrolase of $P_{s e u d o-}$ monas putida. This enzyme hydrolyzed $N$ methylhydantoin to $N$-cabamoylsarcosine in the presence of ATP, $\mathrm{Mg}^{2+}$ and $\mathrm{K}^{+}$. The 5substituted hydantoin hydrolase of $B$. brevis described in this paper was different from the enzyme of $P$. putida because it did not hydrolyze 
$\mathrm{N}$-methylhydantoin in spite of its wide substrate specificity. It was also different from the 5-substituted hydantoin-hydrolyzing enzymes of Flavobacterium sp. ${ }^{101}$ and the other microorganisms ${ }^{13)}$ with regard to ATP dependency and stereospecificity.

The reaction catalyzed by the $N$-carbamoylL-amino acid hydrolase was analogous to the reactions by $\beta$-ureidopropinase (EC 3.5.1.6) ${ }^{14}$ ) and ureidosuccinase $(\mathrm{EC} 3.5 .1 .7)^{15}$ ) with respect to splitting carbamoyl moieties of the substrates to give amino acids. However, the enzyme of $B$. brevis did not act on $N$ carbamoyl- $\beta$-alanine or $N$-carbamoyl-L-aspartate, the substrate of $\beta$-ureidopropinase or ureidosuccinase. The reaction pattern of the L-isomer specific hydrolysis of $\mathrm{N}$-carbamoylL-amino acid to L-amino acids was analogous to that of Flavobacterium sp. ${ }^{10)}$ with regard to stereospecificity. However, the enzyme of $B$. brevis was different from that of Flavobacterium sp. with respect to substrate specificity. The enzyme of $B$. brevis had a wide substrate specificity on aliphatic and aromatic $N$-carbamoyl-L-amino acids but the enzyme of Flavobacterium sp. acted mainly on aromatic $N$-carbamoyl-L-amino acids. The $N$ carbamoyl-D-amino acid hydrolase of Pseudomonas sp. ${ }^{11}$ and the $N$-carbamoylsarcosine amidohydrolase of Pseudomonas putida ${ }^{15}$ were different from the enzyme of $B$. brevis with respect to stereospecificity.

The ATP dependency of the 5-substituted hydantoin hydrolase is supposed to be the limiting factor in the production of $\mathrm{L}$-amino acids from DL-5-substituted hydantoins by the cells of $B$. brevis. In fact, the oxygen supplied to the reaction mixture with moderate shaking greatly promoted the reaction. This suggests that ATP might be well recycled under such conditions. The mechanism of the ATP dependency of the L-5-substituted hydantoin hydrolase is not yet clear, but might be due to the need for energy for the formation of an acylintermediate of the enzyme. For understanding this mechanism, further investigations are required.

Acknowledgments. The authors are indebted to Dr. Y. Komachiya and Dr. R. Tsugawa of our labolatories for their encouragement during the course of this work.

\section{REFERENCES}

1) A. Yamashiro, K. Yokozeki and K. Kubota, Agric. Biol. Chem., 52, 2851 (1988).

2) K. Sano, K. Yokozeki, C. Eguchi, T. Kagawa, I. Noda and K. Mitsugi, Agric. Biol. Chem., 41, 819 (1977).

3) K. Yokozeki, K. Sano, C. Eguchi, K. Yamada and K. Mitsugi, Agric. Biol. Chem., 51, 363 (1987).

4) K. Yokozeki, K. Sano, C. Eguchi, H. Iwagami and K. Mitsugi, Agric. Biol. Chem., 51, 729 (1987).

5) T. Suzuki, K. Igarashi, K. Hase and K. Tsujimura, Agric. Biol. Chem., 37, 411 (1973).

6) H. R. Henze and R. J. Speer, J. Am. Chem. Soc., 64, 522 (1942).

7) G. R. Stark and D. G. Smyth, J. Biol. Chem., 238, 214 (1963).

8) H. Yamada, S. Takahashi, Y. Kii and H. Kumagai, J. Ferment Technol., 56, 484 (1978).

9) M. M. Bradford, Anal. Biochem., 72, 248 (1976).

10) K. Yokozeki, Y. Hirose and K. Kubota, Agric. Biol. Chem., 51, 737 (1987).

11) K. Yokozeki and K. Kubota, Agric. Biol. Chem., 51, 721 (1987).

12) J. M. Kim, S. Shimizu and H. Yamada, Biochem. Biophys. Res. Commun., 142, 1006 (1987).

13) L. L. Campbell, J. Biol. Chem., 235, 2375 (1960).

14) P. Reichard and O. Skold, Meth. Enzymol., 6, 177 (1963).

15) J. M. Kim, S. Shimizu and H. Yamada, J. Biol. Chem., 261, 11832 (1986). 